\title{
Genetic Resources of Sambar Deer (Cervus unicolor) and its Conservation Efforts in Lamandau Regency, Central Kalimantan
}

\author{
Ermin Widjaja ${ }^{1, *}$ Bambang Ngaji Utomo ${ }^{2}$
}

\author{
${ }^{1}$ Indonesia Assessment and Development Center for Agricultural Technology, Bogor, Indonesia \\ ${ }^{2}$ Indonesia Center Research Institute for Veterinary Science, Bogor, Indonesia \\ *Corresponding author. Email: erminwidjaja02@gmail.com
}

\begin{abstract}
One of the livestock genetic resources in Lamandau Regency, Central Kalimantan Province is the Sambar deer (Cervus unicolor). The existence of this deer is threatened because of the conversion of land into plantations. Conservation of genetic resources of Sambar deer is carried out through ex-situ conservation which is managed by the Department of Agriculture, Livestock and Fisheries. Conservation goals for educational tourism. This paper aims to inform the conservation of Sambar deer in Lamandau Regency and the problems it faces. The research method was through field observations and interviews with the person in charge of conservation. The research locations were in Lamandau Regency and West Kotawaringin Regency as a comparison to the conservation model of the sambar deer. The results showed that conservation in West Kotawaringin Regency was managed by the private sector. The conservation location is on the edge of a forest area where the environmental conditions of the conservation area in accordance with their natural habitat, apart from being given additional feed, deer can find their own food in the conservation site. Conservation in Lamandau District is managed by the Department of Agriculture, Livestock and Fisheries in a city park as a tourist location by providing forage feed and additional concentrates from palm oil waste. In the population from 26 in November 2019 to 29 in September 2020, 3 individuals of sambar deer died due to the extreme conditions of the very hot dry season, as well as the presence of worms. The local government is very supportive of the sambar deer conservation efforts.
\end{abstract}

Keywords: conservation, Lamandau, problems, sambar deer

\section{INTRODUCTION}

Sambar deer in Indonesia are divided into two types [1], spread over two large islands, namely Sumatra and Kalimantan [1], [2], with sub-species of deer from Kalimantan having larger postures compared to those in Sumatra [1]. The Sambar deer is the largest deer in Indonesia, compared to other deer species found in Indonesia such as the Timor deer (Cervus timorensis), Bawean deer (Axis kuhlii), and ordinary deer (Muntiacus muntjak) [2]. The Sambar deer that inhabits Indonesia are a subspecies of Cervus unicolor equinus which can also be found on the Malaysian and Thai peninsulas.

The population of Sambar deer is reported to have decreased as a result of hunting [3]. Because deer have a high economic value, because almost everything in deer, namely skin, rangga (young horns), and meat can be used. In certain cities, you can find food stalls selling deer meat openly. They claim to get deer from local communities from hunting. In East Kalimantan Province, it has been reported that the hunting rate of Sambar deer is high, reaching thousands per year [1]. This condition is exacerbated by the lack of public knowledge about the protection status (conservation) of the Sambar deer. Efforts to protect the Sambar deer from extinction have begun to be made, for example in East Kalimantan, South Kalimantan, Central Kalimantan and also in Sumatra.

Based on PP No. 7 of 1999, the four species of deer native to Indonesia are included in protected animals. In the IUCN (International Union for Conservation of Nature and Cultural Resource) Redlist, sambar and Timor deer are categorized as Vulnerable (VU; Vulnerable), which is a conservation status given to species that are at risk of extinction in the wild in the future. Seeing the threat 
of hunting which could result in a decline in population, made him not to be careless in order to always protect the preservation of this largest deer to remain a wealth of Indonesian biodiversity.

Sambar deer was still found in the forest of Lamandau District, but the exact population is not known. Captive breeding efforts have begun to be tried, not only in Lamandau district but in neighboring districts, namely West Kotawaringin Regency, Sambar deer have also started to be bred. The purpose of this paper is to inform the captive management (ex situ conservation) of Sambar deer in Lamandau Regency which is supported by information from literature studies.

\section{MATERIALS AND METHODS}

Activities carried out through direct field observations in the Sambar deer breeding to see the maintenance management (drums, feed, environment and deer performance) both in Lamandau and West Kotawaringin districts as a comparison. Information and data were obtained through interviews with the person in charge of breeding the Sambar deer as primary data. Specifically, for disease monitoring, it focuses on worm disease through examination of deer dung and carcass surgery on dead deer. The data and information obtained were tabulated and analyzed descriptively according to the desired objectives.

\section{RESULT AND DISCUSSION}

\subsection{Knowing Sambar Deer}

Information about Sambar deer in terms of performance, habitat and reproduction can be a reference for the implementation of Sambar deer breeding, where maintenance management is made as closely as possible to its natural habitat. Given that deer have a tendency to choose new areas according to habitat components that are close to or in accordance with the habitat needed in an effort to conserve their offspring.

\subsection{The performance of the Sambar Deer}

Sambar deer in Lamandau Regency as well as other Sambar deer species has a large body size compared to other deer species. The large, tall and well-built posture is especially visible in the male. Sambar deer are tropical deer that are the largest in size in Asia. The body size of male sambar can reach $225 \mathrm{~kg}$ and female $135 \mathrm{~kg}$ [4].

According to [5], deer have specific antlers consisting of cartilage networks that are structurally different from antlers consisting of keratinized tissue.
The shape and structure of the deer antler is specific to each species. In the Sambar deer, the antelope structure consists of the first branch which is located at the bottom, called brow tines, while the second branch with two ends, each with inner top tines which is located on the inside and outer top tines on the outside.

\subsection{Natural Habitats of Sambar Deer}

The natural habitat of Sambar deer is brackish or watery forest [6]. The natural habitat of deer consists of several types of vegetation such as savannas that are used as a source of feed and forest vegetation that is not too tight for shelter (rest), mating and avoiding predators. Forest to an altitude of 2,600 $\mathrm{m}$ above sea level with grasslands is the most preferred habitat for deer, especially Cervus timorensis, except for Cervus unicolor which most of its daily activities are carried out in brackish areas [7]. From the results of research that has been carried out, it turns out that the Sambar deer has a high adaptation to its environment so that it is easy to breed [8]. For example, in Lamandau and West Kotawaringin (Kobar) districts, the Sambar deer are developing well along with the development of oil palm plantations in the Sambar deer habitat.

Male deer in their natural habitat prefer solitary life (solitare), while for females form a family group with family members consisting of up to one or two chicks either born or born in the previous year. The daily behavior of deer in nature is generally nocturnal, which means that they are active foraging in the dark [2].

\subsection{Reproduction Characters of Sambar Deer}

Sambar deer are productive wild animals, because they can reproduce every year and have a high level of production with a higher percentage of carcass than other animals. The active reproductive period of deer starts from the age of 1.5-12 years and the maximum age that can be reached is around 15-20 years [9]. The birth pattern of deer throughout the year. The results of research conducted by [10] in captivity show that the conception rate is very low, with an average of $48.8 \%$. Assuming the mean length of gestation is 240 days, then the natural lactation period for fawn born in captivity is 148 days $( \pm 5$ months). The first time a young female deer gave birth was identified at the age of 693.8 days (SD 89.40 days; $n$ 4), which means that the first conception occurred at the age of about 453 days $( \pm$ 15 months) [10]. The very low mean percentage of births (49\%) according to [11] is a matter that should get attention from a marriage management 
perspective. The percentage of Sambar fawn births in captivity in New Zealand is only $78 \%$ by [11]. The percentage of births in Timor deer in Mauritius and New Caledonia is between $80-100 \%$ [12], [13] and in Australia between 90-97\% [14].

\subsection{The Sambar Deer Captivity in Lamandau District}

\subsubsection{Description of Lamandau District}

The area of Lamandau Regency with an area of 622,811 hectares consists of 8 (eight) districts, namely Bulik, Bulik Timur, Menthobi Raya, Sematu Jaya, Lamandau, Belantik Raya, Batangkawa, and Delang Districts and geographically located at coordinates $01^{\circ} 20$ '17"- $02^{\circ} 18^{\prime} 43^{\prime \prime}$ South Latitude and $110^{\circ} 51^{\prime} 32^{\prime \prime}-111^{\circ} 43^{\prime} 55^{\prime \prime}$ East Longitude. Areas that are close below the equator receive sufficient solar radiation throughout the year with an average minimum temperature of $22.6^{\circ} \mathrm{C}$ and a maximum temperature of $32.08^{\circ} \mathrm{C}$. The temperature difference between locations is relatively small and is only distinguished by differences in altitude. The relative temperature during the day ranges from $26^{\circ} \mathrm{C}-30^{\circ} \mathrm{C}$ while at night $20^{\circ} \mathrm{C}-26^{\circ} \mathrm{C}$, with an average value of $85 \%$ relative humidity [15]. The current land use pattern (present land use) in the Lamandau area is generally still dominated by forest areas, in several other areas there are shrubs, shrubs and swamps. BPS data until 2018 states that the total area of the area which is a combination of protected forest, limited production forest and that can be converted reaches 537,901 hectares or $86.37 \%$ of the total area of Lamandau.

The condition of the scrub habitat in this area is surrounded by freshwater swamp forest on the edges, so that in addition to providing adequate food, this area is according to [16] is a good protection for sambar deer, especially at feeding time. In addition, this area also has water availability that continues throughout the year in its small rivers. The combination of temperature and humidity regimes can be used as the basis for classifying the environment in which certain plants and animals can grow well, including the Sambar deer. Thus, the condition of Lamandau Regency is ideal for breeding of Sambar deer.

\subsubsection{The potential of Sambar Deer}

Sambar deer have high adaptability to new environments ([17], [7]) so that they are easy to breed or to be conserved ex situ. In addition to protecting these animals, deer breeding is generally used for tourism purposes. According to [18] in Indonesia it has not been cultivated commercially in animal husbandry unlike abroad for various purposes such as producing meat (venison) and for the production of young antlers.

Deer have the potential to be developed for the purpose of producing meat because these animals are very efficient in using feed to be converted into meat [17]. According to [19] stated that deer can convert $30 \mathrm{~kg}$ of dry matter to $3 \mathrm{~kg}$ of meat. Another advantage over cows according to [17] is that it has a higher protein content and a lower fat content. Protein content of deer meat $21.1 \%$ and $18.8 \%$ beef; fat content of deer meat $7.0 \%$ and beef $14.0 \%$.

Although deer are protected wildlife, they can also be used for livestock production [3]. Therefore, the development of deer as livestock is one of the best solutions in terms of protection and utilization of wildlife. However, in utilization there are regulations that require the second derivative product (F2) to be captive. The technical regulations for implementation are regulated in PP No.8 of 1999 with the use of wild animals so that they can be used sustainably and for the greatest prosperity of the people [3]. Furthermore, the Decree of the Minister of Agriculture No 362/KPTS/TN/12/V/1990 on May 20, 1990, included deer into a group of various livestock that can be cultivated like other livestock, including regulating business permit regulations. The breeding place for Sambar deer in Indonesia which has successfully developed its production and reproductive potential is in East Kalimantan Province [20].

Deer breeding is an effort to reproduce through breeding and enlargement outside of natural habitat (ex-situ) while maintaining the purity of its species. Utilization of the results of captivity in the form of first offspring (F1) can be transferred to other breeders as parent, while second offspring (F2) and so on can be traded.

Lamandau District itself has tried to breed the Sambar deer even though it is still limited to protecting it from extinction and as a tourist attraction. This is a very good step considering the presence of deer in Lamandu is increasingly threatened due to the increasing extent of clearing forest areas to non-forest, such as for oil palm plantation development, which reported that the area of oil palm plantations in Lamandau was reported in 2018 to reach $30,074.8$ ha [15], which causes the habitat of the Sambar deer getting more and more pressed.

\subsubsection{Deer Population and Reproduction in Captivity}

The population of Sambar deer in Lamandau Regency is difficult to know because there has been 
Table 1. Population development of the Sambar deer (Cervus unicolor) in the conservation Lamandau Regency, Central Kalimantan

\begin{tabular}{|c|c|c|c|c|c|c|c|c|c|}
\hline \multirow[t]{2}{*}{ No } & \multirow[t]{2}{*}{ Type } & \multicolumn{3}{|c|}{$\begin{array}{l}\text { F0 (tail) Initial } \\
\text { population }\end{array}$} & \multicolumn{3}{|c|}{ Heredity } & & \multirow[t]{2}{*}{ Information } \\
\hline & & $0^{7}$ & Q & Amount & F1 & F2 & Amount & Total & \\
\hline 1. & $\begin{array}{l}\text { Sambar Deer } \\
\text { Distribution in } 2016 \\
\text { Population as of } \\
\text { November } 2019\end{array}$ & 2 & 5 & 7 & 4 & & 4 & 11 & $\begin{array}{l}\text { Born: } \\
16 \text { October } 2018 \\
31 \text { October } 2018 \\
\text { 01 July } 2019 \\
\text { 30 October } 2019\end{array}$ \\
\hline 2. & $\begin{array}{l}\text { Sambar deer } \\
\text { Distribution in } 2017 \\
\text { Population as of } \\
\text { November } 2019\end{array}$ & 4 & 6 & 10 & 5 & & 5 & 15 & $\begin{array}{l}\text { Born: } \\
\text { 2nd February } 2017 \\
\text { 15th February } 2017 \\
\text { 4th October } 2017 \\
\text { 14th October } 2017 \\
\text { 29th November } 2017 \\
\text { 22th January } 2018 \\
\text { 2nd January } 2019 \\
\text { Dead: } \\
\text { 13rd May } 2018\end{array}$ \\
\hline 3. & November 2020 & & & & 3 & & & 3 & Dead 3 individuals \\
\hline & & & $\mathrm{TO}$ & & & & & 26 & \\
\hline
\end{tabular}

no research specifically to predict the population of Sambar deer in the deer habitat area in Lamandau Regency. The current population in the captive breeding site which has been carried out since 2016 is 26, of which there have been two distributions, namely 7 in 2016 and 10 in 2017. The results of the survey on the development of the Sambar deer during captivity are presented in detail in Table 1.

Births occur almost every year and are most commonly reported in October. However, there are still reports of deaths, especially in children. The results of research by [10] show that births also occur frequently in October and indicators of the success of developing a captive population can be seen from the productivity of the mother and the percentage of live children at 12 months of age.

\subsubsection{Maintenance management in captivity in Lamandau District}

Sambar deer is designated as an icon of the city of Nanga Bulik, the capital of Lamandau Regency. Given that the Sambar deer is one of the protected animals by the government, the local government of Lamandau Regency is committed to breeding and protecting the deer (Cervus unicolor). Currently, the maintenance of captivity is borne by the Agriculture Livestock and Fisheries Office of Lamandau District. The local government has allocated 17 hectares of urban forest land as a conservation area and 1 hectare of its own enclosure, namely in the form of a high fenced area for the movement of Sambar deer activities.

The focus of current captive activities is to keep the Sambar deer healthy and breed well. The conservation area is open to the public so that people can come to see, learn, as well as a tourist attraction (Figure 1). According to [7] there are several things that must be considered related to the captivity of the Sambar deer, namely habitat components consisting of feed, water, shade and space.

Sambar deer in their natural habitat use lowland forest vegetation, freshwater swamp forests, grasslands and shrubs as a source of food [12] thus the staple food of Sambar deer is forage in the form of leaves and grass [20], [21. To keep the Sambar deer healthy in captivity in Lamandau Regency, the feed given is cassava, rambans and weeds which are strived for their type of feed to be close to their natural habitat (Figure 2). Rambans in the form of wild leaves and grass are obtained around residential areas. According to [23] and [16] grasses and forage are favored by deer. In addition to forage, additional feed or concentrate is also given in the form of waste from the palm oil mill industry which is widely available in Lamandau Regency which is processed into concentrate feed consisting of solid palm oil, palm kernel oil, minerals and microbes. Concentrated feed from palm oil industrial waste was introduced by [24] in Lamandau Regency for cattle feed. The concentrate is given by mixing it with grass. According to [25] stated that combining forage and 


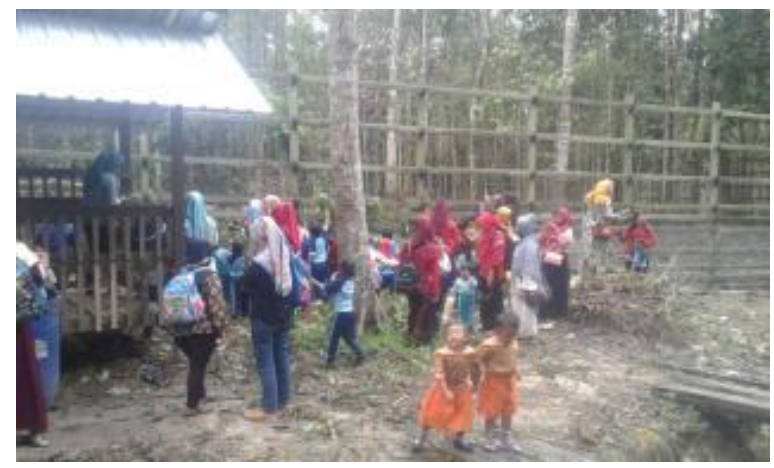

Figure 1. Sambar captive breeding in Lamandau District as an educational facility

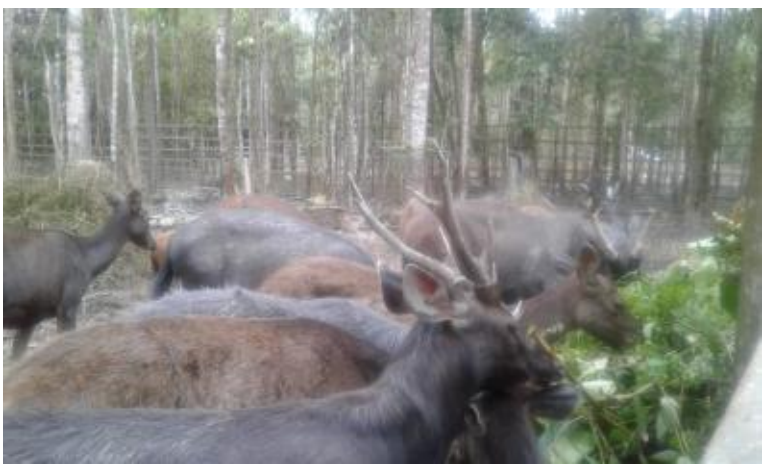

Figure 2. Deer feed in the form of forage leaves and grass in the Sambar deer captivity in Lamandau District

concentrate feeding will provide a significant increase in body weight growth. The observations show that if the feed given is lacking (quality and quantity) the deer performance quickly decreases. Feed according to [26] greatly affects the production and reproduction of deer. So that [16] recommend paying more attention to feed factors.

This is different from the captivity carried out by the private sector in West Kotawaringin Regency. Where the deer are made a separate area on the edge of the forest without a drum and the deer can roam back into the forest (Figure 3 ). The feed provided is elephant grass embedded in the ground so that the deer can eat directly without being disturbed and also to maintain the safety of the officers who provide the feed. Deer appear tame but can become aggressive when disturbed as also reported by [27].

The results of the examination of 9 samples of deer manure were found to be positive for 7 samples of trematode worms, 1 sample of nematodes and 5 samples of cestodes, even 2 of them were found to be positive for Fasciola sp. These results were confirmed by carcass surgery on dead deer where many worms were found in the rumen (Figure 4).

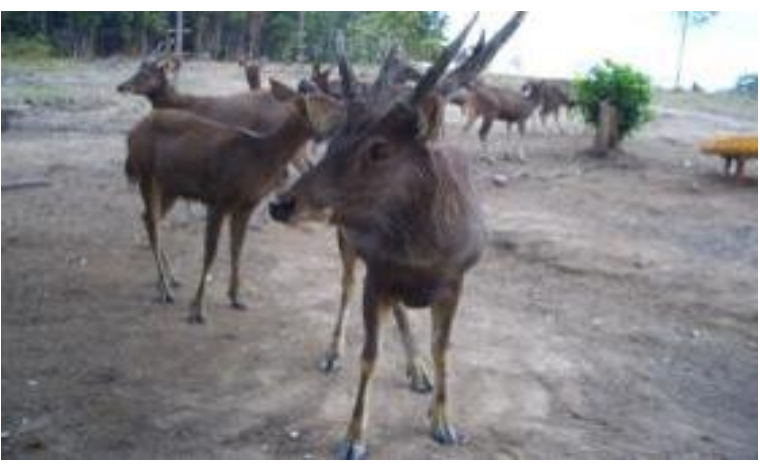

Figure 3. Sambar deer in captivity in Kotawaringin Barat District, Central Kalimantan

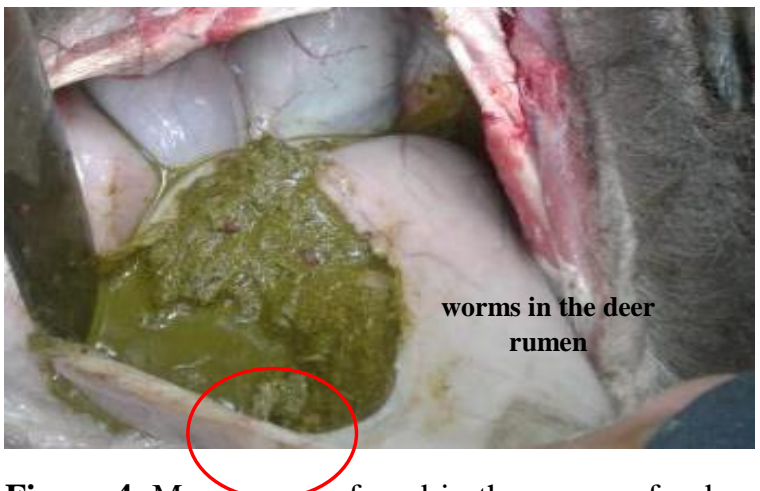

Figure 4. Many found in the rumen of a deer (red circle)

Fasciola is the cause of heartworm that affects various livestock including deer. This disease can inhibit livestock growth and become a predisposing factor for other diseases or secondary infection [28]. Other types of worms found were Monieza sp., Paramphistomum sp, and Trichostrongylus sp. The impact of this worm disease, even though the feed is given in sufficient quantities and is always available in the cage, the fact is that the body is still thin. According to [29] reported that the prevalence of Paraphistomum sp. in Sambar deer reaches $100 \%$ and can cause body weight loss. Health handling of the Sambar deer in captivity is still constrained by related budgets for repairs to cages, revamping its environment and providing medicines for handling its health aspects.

\section{CONCLUSION}

The Sambar deer breeding approach in Lamandau District is in addition to preservation but is focused for the time being for tourism purposes and as a means of educating the public about the importance of preserving Sambar deer. The adaptability of the Sambar deer in captivity is quite high but the problem of worms needs to be considered, handling is still constrained by the provision of medicines. There is 
still a need for commitment from the local government to pay more attention to the future prospects of the Sambar deer breeding in Lamandu Regency.

It is important to ground information regarding the potential, development prospects and use of the Sambar deer, so it is hoped that many parties will be interested and moved to save the Sambar deer from extinction through sustainable use activities. Conservation activities through captivity of the Sambar deer in Lamandau Regency to support its development efforts in captivity, exploratory research needs to be carried out. Data such as body weight, body dimensions and reproduction specifically for Sambar deer in Lamandau Regency are needed to predict production potential and opportunities for increased productivity through breeding technology. The problem of disease management needs attention given its impact on animal productivity. Apart from providing medicines, arranging the cage and its environment to maintain the health and comfort of the animals must also receive attention.

\section{ACKNOWLEDGMENT}

Thank you very much to the Head of the Agriculture, Livestock and Fisheries Services of Lamandau Regency, drh. Tirto for the support and their assistance in the field.

\section{REFERENCES}

[1] G.Y. Semiadi, Jamal, W.R. Farida, M. Muchsinin, Kualitas daging rusa sambar (Cervus unicolor) hasil buruan di Kalimantan Timur, Animal Production 5(1) (2003) 35-41. [In Bahasa Indonesia]

[2] R.B. Suba, C.D. Boer, Irman, Informasi dari feses dan jejak kaki rusa Sambar (Cervus unicolor) serta implikasinya pada akurasi penaksiran populasi, Jurnal Ilmu Kehutanan 4(2) (2010) 70-79. [In Bahasa Indonesia]

[3] Wirdateti, B. Brahmantiyo, A. Reksodiharjo, G. Semiadi, H. Dahruddin, Karakteristik morfometrik rusa sambar (Rusa unicolor) sebagai dasar kriteria seleksi sifat pertumbuhan, Jurnal Veteriner 10(1) (2009) 7-11. [In Bahasa Indonesia]

[4] S. Indriyani, B.S. Dewi, N.W. Masruri, Analisis preferensi pakan drop in rusa sambar (Cervus Unicolor) dan rusa totol (Axis axis) di penangkaran PT. Gunung Madu Plantations Lampung Tengah, Jurnal Sylva Lestari 5(3) (2017) 22-29. [In Bahasa Indonesia]
[5] R. Anderson, Gold on four feet. Ronald Anderson Assoc. Pty. Ltd. Melbourne, 1978

[6] E. Nurrahmadani, Upaya pelestarian rusa sambar di pusat penangkaran rusa di Desa Apiapi, Kecamatan Waru, Kabupaten Penajam Paser Utara, Jurnal Beraja Niti, 2(9) (2013) 2 10. [In Bahasa Indonesia]

[7] R. Garsetiasih, M. Takandjandji, Model penangkaran rusa, Prosiding Ekspose HasilHasil Penelitian Konservasi dan Rehabilitasi Sumberdaya, 2007. [In Bahasa Indonesia]

[8] G. Semiadi, Sifat biologi rusa bawean (Axis kuhlii) [Biological aspect of Bawean Deer (Axis kuhlii)], Puslit Biologi LIPI Press, Bogor, 2004

[9] R. Garsetiasih, N. Herlina, Evaluasi plasma nutfah rusa totol (Axis axis) di halaman Istana Bogor, 2004. [In Bahasa Indonesia]

[10] G. Semiadi, I.G.M.J. Adhi, A. Trasodiharto, Pola kelahiran rusa sambar (Cervus unicolor) di penangkaran Kalimantan Timur, Biodiversitas 6(1) (2005) 59-62. [In Bahasa Indonesia]

[11] G. Semiadi, P.D. Muir, T.N. Barry, General biology of sambar deer (Cervus unicolor) in captivity, New Zealand Journal of Agricultural Science 37 (1994) 79-85.

[12] M. Bianchi, S. Lebel, J.C. Hurlin, P. Humblot, P. Chardonnet, M. Thibier, Reproductive pattern of rusa deer (Cervus timorensis russa) in New Caledonia, in: Milne, J.A (ed.). Recent Developments in Deer Biology, Aberdeen, U.K.: Macaulay Land Use Research Institute, 1994.

[13] J.A. Lalouette, Development of deer farming in Mauritius, in: P.F. Fennessy, K.R. Drew (eds.) Biology of Deer Production, Proceedings. The Royal Society of New Zealand Bulletin 22 (1985) 379-380.

[14] S. Van Mourik, Reproductive performance and maternal behaviour in farmed rusa deer (Cervus timorensis russa), Applied Animal Behaviour Science 15 (1986) 147-159.

[15] BPS Kabupaten Lamandau, Statistik Daerah Kabupaten Lamandau, Nanga Bulik, 2019. [In Bahasa Indonesia]

[16] A.H. Mustari, A. Manshur, B. Masyud, Jenis pakan dan daya dukung habitat rusa sambar (Cervus Unicolor Kerr, 1972) di Resort Teluk Pulai, Taman Nasional Tanjung Puting, Kalimantan Tengah, Media Konservasi 17(2) (2012) 47-54. [In Bahasa Indonesia] 
[17] T. Atmoko, Prospek dan kendala pengembangan penangkaran rusa sambar (Cervus unicolor brookei), Prosiding Seminar Pemanfaatan HHBK dan Konservasi Biodiversitas menuju Hutan Lestari, Balikpapan, 2007, pp. 118-123. [In Bahasa Indonesia]

[18] W. Nurcahyo, A.S. Drajat, Djuwantoko, Penangkaran rusa sebagai pendukung agroforestri: tatalaksana, pemasaran dan ekonomi, Proceeding Seminar Nasional Peranan Strategis Agroforestri dalam Pengelolaan Sumberdaya Alam Secara Lestari dan Terpadu, Yogyakarta, 2002. [In Bahasa Indonesia]

[19] A.S. Dradjat, Potensi biologi dan reproduksi rusa sebagai hewan ternak, Seminar Prospek Penangkatan Rusa di Indonesia. Yogyakarta, 2002. [In Bahasa Indonesia]

[20] M. Muchsinin, G. Semiadi, A. Dradjat, W.R. Farida, Developing sambar deer as new domesticated animal in East Kalimantan, in: Ungulate Bioecology and Conservation Seminar; Bogro, Indonesia. Proceeding, 2002, pp. $61-68$

[21] A.S. Mukhtar, N.M. Heriyanto, Keadaan suksesi tumbuhan pada kawasan bekas tambang batu bara di Kalimantan Timur, Jurnal Penelitian Hutan dan Konservasi Alam, 9 (2) (2012) 341350. [In Bahasa Indonesia]

[22] A. Ma'ruf, T. Atmoko, I. Syahbani, Teknologi penangkaran rusa sambar (Cervus unicolor) di Desa Api-APi, Kabupaten Penajam, Pasir Utara, Kalimantan Timur, Makalah Utama pada Gelar dan Dialog Teknologi, Mataram, 2005. [In Bahasa Indonesia]

[23] D.A. Amiati, B. Masyud R. Garsetiasih, Pengaruh pengunjung terhadap perilaku dan pola konsumsi rusa timor di Hutan Penelitian Dramaga, Buletin Plasma Nutfah 21(2) (2005) 47-60. [In Bahasa Indonesia]
[24] E. Widjaja, B.N. Utomo, B. Haryanto, A. Firmansyah, T. Rahmawati, Sunarto, E. Purba, Model pertanian Bio-Industri Berbasis Integrasi Sawit-Sapi di Kabupaten Lamandau. Kalimantan Tengah. Laporan akhir kegiatan KKP3SL 2015, Badan Penelitian dan Pengembangan Pertanian, 2016. [In Bahasa Indonesia]

[25] G. Semiadi, R.T.P. Nugraha, Panduan pemeliharaan rusa tropis, Bogor, Pusat Penelitian Biologi LIPI, 2004. [In Bahasa Indonesia]

[26] R. Gusmalinda, B.S. Dewi, N.W. Masruri, Perilaku sosial rusa sambar (Cervus Unicolor) dan rusa totol (Axis Axis) di kandang penangkaran PT. Gunung Madu Plantations Lampung Tengah, Jurnal Sylva Lestari 6(1) (2018) 74-84. [In Bahasa Indonesia]

[27] Elfrida, S. Jayanthi, N. Rahayu, Aktivitas harian rusa tutul (Axis axis) pada lahan konservasi di hutan kota Kecamatan Langsa Baro Kota Langsa, Jurnal Biotik 7(1) (2019) 8-17. [In Bahasa Indonesia]

[28] F. Rosi, J. Handoko, R. Febriyanti, Infestasi cacing hati (Fasciola sp.) dan cacing lambung (Paramphistomum sp.) pada sapi bali dewasa di Kecamatan Tenayan Raya Kota Pekanbaru, Jurnal Sain Veteriner 33(1) (2015) 8-15. [In Bahasa Indonesia]

[29] M. Tanjung, Nursal, H.L. Sibarani, Species and prevalence of endoparasites on the feces of sambar deer (Cervus unicolor) and spotted deer (Axis-axis) in conservation Universitas Sumatera Utara. SEMIRATA- International Conference on Science and Technology 2018 IOP Publishing. IOP Conf. Series, Journal of Physics, Conf. Series 1116 (2018) 052070 doi:10.1088/1742-6596/1116/5/052070 